\title{
Ghostly Surrogates and Unhomely Memories: Performing the Past in Marina Carr's Portia Coughlan
}

\section{Shonagh Hill}

\section{(2) OpenEdition Journals}

Electronic version

URL: http://journals.openedition.org/etudesirlandaises/3065

DOI: 10.4000 /etudesirlandaises.3065

ISSN: 2259-8863

Publisher

Presses universitaires de Rennes

\section{Printed version}

Date of publication: 30 June 2012

Number of pages: 173-187

ISSN: 0183-973X

\section{Electronic reference}

Shonagh Hill, « Ghostly Surrogates and Unhomely Memories: Performing the Past in Marina Carr's Portia Coughlan », Études irlandaises [Online], 37-1 | 2012, Online since 30 June 2014, connection on 19 April 2019. URL : http://journals.openedition.org/etudesirlandaises/3065 ; DOI : 10.4000/ etudesirlandaises.3065 


\title{
Ghostly Surrogates and Unhomely Memories: Performing the Past in Marina Carr's Portia Coughlan
}

\author{
Shonagh Hill \\ St. Patrick's College, Drumcondra, Dublin
}

Abstract

In Marina Carr's Portia Coughlan (1996) ghostly performances stage the unsettling effects of the past as it resurfaces in the present; of both individual memory and the cultural memory of female experience. Through application of Joseph Roach's concepts of surrogation, genealogies of performance and environments of memory, as well as Homi K. Bhabha's unhomely, this article argues that Portia's haunted body embodies and resists inherited myths of an idealized and domesticated passive Irish femininity.

Keywords: Marina Carr, myths of femininity, memory, ghosts, haunting, genealogies of performance, environments of memory, unhomely.

\section{Résumé}

Dans la pièce de Marina Carr Portia Coughlan (1996), la présence des fantômes met en scène les effets perturbants du passé quand il refait surface à la fois dans la mémoire individuelle et dans la mémoire culturelle de l'expérience des femmes. À travers les concepts de substitution, de généalogie de la performance et d' environnement de la mémoire, ainsi que du concept de non-familier formulé par Homi K. Bhabha, cet article montre que le corps hanté de Portia incarne et repousse tout à la fois les mythes reçus en héritage d'une féminité irlandaise idéalisée, passive et domestique.

Mots clé : Marina Carr, mythes de féminité, mémoire, fantômes, hantise, généalogies de la performance, environnements de la mémoire, non-familier.

Memory relies on citation and repetition, and its reperformance in the present serves to transmit and reinvent the past. Key to a feminist project of reclaiming unrepresented female experiences and envisioning a different future through dialogue with this past is the process of reassessing dominant narratives of history and cultural memory. The reappearance of spectres of the past onstage can potentially prompt an excavation of the forgotten layers of embodied history; addressing the exclusion of particular experiences from collective memory and thus how cultural memory shapes gendered and national identities. In Marina Carr's Portia Coughlan (1996) ghostly performances stage the unsettling effects of the past as it resurfaces in the present; of both individual memory and the cultural memory 
of female experience as defined by limiting myths of an idealized and domesticated passive Irish femininity. This article will focus on the haunted body in order to examine the processes of memory and history as layers of somatic memories which are exposed and reperformed. Furthermore, I will address how performance can highlight the body as a site of memory, history and forgetting.

History and memory are narratives which can be fixed and memorialized, so how do we engage theatrically with history as continual process in order to open up these concealed pasts? In Cities of the Dead: Circum-Atlantic Performance, Joseph Roach examines the cultural activity of the circum-Atlantic region as embodied through performance. In order to examine the extent to which Portia Coughlan is trapped in a cycle which reaffirms the past, I will employ several of Roach's key concepts: surrogation, genealogies of performance and environments of memory. In The Location of Culture, Homi K. Bhabha develops Freud's notion of the uncanny, characterised by the disquieting return of the familiar in an unfamiliar context, as the unhomely whose re-emergence disturbs the boundaries of what is private and public: "The unhomely moment relates the traumatic ambivalences of a personal, psychic history to the wider disjunctions of political existence ${ }^{1}$." Furthermore, Bhabha's unhomely can address the embodied experience of performance: subversive and uncanny performances of the past which question cultural memory. Roach's and Bhabha's work describes the resurfacing of the repressed and forgotten through the performing body and offers the means to address the potentially destabilizing and uncanny effects of performing elided pasts. Alice Rayner suggests that ghosting should retain an element of uncertainty and the uncanny: "Making full use of the term ghost and haunting involves, it seems to me, their remaining in the realm of uncertainty ${ }^{2}$." Do the ghosts of Portia Coughlan perpetuate a purgatorial space of congealed history and memory, or can production choices, such as direction, lighting and set design, utilise these ghosts to address the unhomely past and displace inherited models of femininity?

Carr's early plays Low in the Dark (1989) and Ullaloo (1991) interrogate the performance of gender through an experimental absurdist form. The three plays which followed, The Mai (1994), Portia Coughlan (1996) and By the Bog of Cats... (1998), marked a shift towards a style which blends heightened realism with mythic allusion, yet is firmly set in an Irish Midlands locale. Carr's more recent Woman and Scarecrow (2006) marked a return to a less realist and more experimental style, yet despite changes in theatrical form, Carr consistently engages with representations of Irish woman and the expression of female subjectivity. The closing decade of the twentieth century witnessed positive changes for Irish women including the election

1. Homi K. Bhabha, The Location of Culture, London, Routledge, 1994, p. 11.

2. Alice Rayner, Ghosts: Death's Double and the Phenomena of Theatre, Minneapolis and London, The University of Minnesota Press, 2006, p. XxiII. 
of a female president, changes in divorce laws and fierce debate over abortion laws. Pat O'Connor has drawn attention to the "widespread misperception of the gender of what has become known as the Celtic Tiger, in a situation where male employment has been virtually static and female employment has increased dramatically". However, despite these changes, women still have to negotiate the legacy of restrictive models of femininity as enshrined in the extant Article 41 of the 1937 Constitution of Ireland which places women in the domestic sphere and grants the role of mother dominance over other models of femininity:

2.1. In particular, the State recognises that by her life within the home, woman gives to the State a support without which the common good cannot be achieved. 2.2. The State shall, therefore, endeavour to ensure that mothers shall not be obliged by economic necessity to engage in labour to the neglect of their duties in the home ${ }^{4}$.

Carr's three Midlands plays are centred on women who reject the gendered confines of her environment through suicide. This article is concerned with the ways in which Portia's performance embodies and resists the traces of the past.

Portia Coughlan is set on Portia's thirtieth birthday which is also the fifteenth anniversary of the death of her twin brother Gabriel. Gabriel haunts Portia and the play throughout, both visually when the audience see his ghost and aurally as he is evoked by singing. Act I charts the early part of the day and Portia's encounters with her husband Raphael and her parents, who criticise her for neglecting her "duties" as a mother and wife. Portia's conversations with lovers and friends highlight her discontent in her home, while her desire to be reunited with Gabriel is connected to the alternative space of the Belmont River, where he drowned. Act II opens with the recovery of Portia's drowned body and the community's reaction to this, while Act III returns to the hours that lead to her suicide. In the third act Portia's arguments with Raphael and her mother further focuses our attention on the notion of the "natural mother". I will argue that Portia's actions in the final scene of the play see her fulfilling, and ultimately rejecting, her duties as mother and wife. Textual analyses of Carr's work, such as Clare Wallace's Suspect Cultures: Narrative, Identity and Citation in 1990s Drama, suggest that the chronological reversal of Acts II and III, a structure of "echoes and return", connotes inevitability and tragic destiny ${ }^{6}$. Thus the

3. Pat O'Connor, Emerging Voices: Women in Contemporary Irish Society, Dublin, Institute of Public Administration, 1998, p. 256.

4. Department of the Taoiseach - Constitution of Ireland - Bunreacht Na hÉireann. November 2004. Government of Ireland, [http://www.taoiseach.gov.ie/index.asp?docID=243], Accessed March 2010.

5. Marina Carr, Portia Coughlan, in Plays One, London, Faber and Faber, 1999, p. 233.

6. Clare Wallace, Suspect Cultures: Narrative, Identity and Citation in 1990s New Drama, Prague, Litteraria Pragensia, 2006, p. 261. 
implication is that Portia's suicide is the fulfilment of her desire for re-union with Gabriel and therefore an embrace of a lost past. In contrast, Cathy Leeney highlights Carr's narrative disruption of the linear certainties of the realist form, as well as Carr's utilisation of the instabilities of stage space and dramatic language $^{7}$. Like Leeney, I am interested in how Carr's work "may under certain performance conditions, impress upon an audience not defeat, silence or obliteration but thrilling, moving exhilarating life ${ }^{8}$.

In Hysteria, Trauma and Melancholia: Performative Maladies in Contemporary Anglophone Drama, Christina Wald asserts that Portia is shaped by her experience as a melancholic. My focus on cultural memory and the perpetuation of models of femininity overlaps with Wald's proposal that "Portia's melancholic state involves a profound failure, or refusal, to fulfil the gender expectations of her environment ${ }^{9}$ ". However, I differ from Wald's interpretation of Portia's suicide as solely a result of her melancholic state and her obsession with, and submission to, a lost past: "Portia's melancholic perception, which is so profoundly preoccupied with the past that it cannot envision a non-determined, open future ${ }^{10}$." Though Portia's individual memories may manifest an obsession with Gabriel, the cultural memories addressed by the play serve to conceive of the need for alternative futures as suggested in the space of the Belmont River. Through the prism of Roach's work I would like to reconsider Portia's actions as an engagement with and rejection of the cultural memory of Irish women's experiences: the repression of female subjectivity by restrictive models of domesticated femininity. In addition to Gabriel's presence, the audience are presented with a second ghost: Portia's ghostly performance of restrictive feminine roles in Act III as an engagement with cultural memory. Portia feels suffocated by the roles of mother and wife, resulting in her otherworldly description of herself: "Ah'm dead Maggie May, dead an' whah ya seen this long time gone be a ghost who chan't fin' her restin' place, is all ${ }^{11}$." This article will reference two productions of Portia Coughlan staged on the Peacock stage of the Abbey Theatre, Dublin: the 1996 premiere directed by Garry Hynes with Dearbhla Crotty in the title role and the 2004 production, which was part of the Abbey's centenary

7. Cathy Leeney, "Feminist Meanings of Presence and Performance in Theatre: Marina Carr's Portia Coughlan", Opening the Field, Irish Women: Texts and Contexts, Patricia Boyle Haberstroh and Christine St Peter (ed.), Cork, Cork University Press, 207, p. 92-101, p. 99.

8. Ibid., p. 92.

9. Christine Wald, Hysteria, Trauma and Melancholia: Performative Maladies in Contemporary Anglophone Drama, Basingstoke, Palgrave Macmillan, 2007, p. 190.

10. Ibid., p. 195.

11. Marina Carr, Portia Coughlan, in The Dazzling Dark, Frank McGuinness (ed.), London, Faber and Faber, 1996, p. 293. The play's first publication in The Dazzling Dark (1996) is marked by a strong Midlands phoneticized dialect. Subsequent publication in Plays One (1999) included some adjustments to the text and a more standardized form of English. I will refer to both publications. 
year programme, directed by Brian Brady with Eileen Walsh as Portia. The productions' presentation of ghostly and surrogated bodies interrogate, to varying degrees, performances of the past and the transmission of individual and cultural memory.

\section{Surrogation and the ghosts of individual memory}

Roach highlights the close connection between "memory, performance and substitution" through his concept of surrogation which reproduces cultural memory by inserting substitutes "into the cavities created by loss through death or other forms of departure ${ }^{12}$ ". Roach points to the Mardi Gras krewes of New Orleans as an example of the self-perpetuation of tradition and community: the roles of King Rex and King Zulu are taken on by new people each year but the apparent seamlessness of tradition is maintained through their performance. Following loss, culture reproduces itself through the incessant process of substitution or surrogacy which performs memory and defines identity. However, Roach also highlights the ways in which genealogies of performance and surrogation can doubt the transmission of tradition. While "more than a century of white supremacist entitlement" stood behind King Rex, King Zulu's performance offered "a deconstruction of that white genealogy and the veiled assertion of a clandestine countermemory in its stead ${ }^{13}$ ". This countermemory serves to underline the risks inherent in the process of surrogacy, risks also present in the process of myth-and memory-making, when "befuddled celebrants come to embrace desperate contingencies as timeless essentials ${ }^{14}$ ". Performance choices can enable interrogation of the surrogates in Portia Coughlan as nostalgic performances of an elusive past, and these surrogates can expose the traces and reveal the limits of individual and cultural memory.

Roach describes the construction of an effigy through performance: "They consist of a set of actions that hold open a place in memory ${ }^{15}$." Gabriel's ghost is an effigy whose performance asserts the twins' relationship and represents the past's hold over Portia; a past which she is obsessed with recovering, even through death. Portia articulates Gabriel's function as a surrogate for something that has been lost, though she still desires their union: "Suppose he's not there when I go? [...] Before I was always sure, was the one thing as kept me goin' - Now I don't know any more, and yet I know that somewhere he lives and that's the place I

12. Joseph Roach, Cities of the Dead: Circum-Atlantic Performance, New York, Columbia University Press, 1996, p. 2.

13. Ibid., p. 20.

14. Ibid., p. 30.

15. Ibid., p. 36. 
want to be ${ }^{16}$." Portia's final words of the play suggest that she remains trapped in the past: "And though everyone and everythin' tells me I have to forget him, I cannot, Raphael, I cannot ${ }^{17}$." The stage directions which follow these lines reinforce this interpretation as the play closes with Gabriel's "triumphant" singing. However, the uncanny aspects of Gabriel's ghost can be utilized in performance to undermine memory and Portia's idealization of the past. Freud's uncanny is defined by the troubling reappearance, in an unfamiliar context, of that which has been repressed, the frightening element can be shown to be something repressed which recurs

[...] for this uncanny is in reality nothing new or alien, but something which is familiar and old-established in the mind and which has become alienated from it only through the process of repression ${ }^{18}$.

The unsettling eruption of that which has been wilfully or subconsciously forgotten can thus unfix perpetuated narratives of the past. Alice Rayner suggests that,

if words are successful in naming the ghost, there is no ghost. If the experience of the uncanny does not precede the argument about its undoing of ontology or repetitions of history, it is only an idealization ${ }^{19}$.

Gabriel's ghost incorporates the "undoing of ontology or repetitions of history" as he jeopardizes Portia's ability to function in her world. He threatens her sense of individuated identity as well as undermining her myth of their unity: before drowning he told her, "I'll come back and I'll keep comin' back until I have you ${ }^{20}$ ". As Roach points out, the surrogate threatens to replace the author of its representation ${ }^{21}$, just as Portia's identity is under threat of being subsumed by Gabriel's hold over her. The stage directions for the opening scene of the play set the twins up visually as doubles as " $[\mathrm{t}]$ hey mirror one another's posture and movements in an odd way; unconsciously ${ }^{22}$ ". In relation to the process of surrogation, Roach quotes Bhabha's claim that " $[\mathrm{m}]$ imicry is at once resemblance and menace ${ }^{23}$ ", and as Portia's mirrored double, Gabriel questions and threatens the individuality and reliability of her identity. In the opening scene of the 1996 production, Gabriel stood in the shadows behind Portia so that he visually echoed

16. Marina Carr, Portia Coughlan, in Plays One, London, Faber and Faber, 1999, p. 240.

17. Ibid., p. 255.

18. Sigmund Freud, "The "Uncanny", Art and Literature, Vol. 14, Harmondsworth, Penguin, 1990, p. 363.

19. Alice Rayner, Ghosts: Death's Double and the Phenomena of Theatre, Minneapolis and London, The University of Minnesota Press, 2006, p. xxiIr.

20. Marina Carr, Portia Coughlan, in Plays One, op. cit., p. 250.

21. Joseph Roach, op. cit., p. 6.

22. Marina Carr, Portia Coughlan, in Plays One, op. cit., p. 193.

23. Joseph Roach, op. cit., p. 6. 
her, thus serving an uncanny purpose through highlighting Portia's potential to function as a surrogate and her living death.

As a reflection of Portia, Gabriel creates the uncanny sense that Portia is living a ghostly existence: his ghost mirrors Portia's own unfulfilled life. Portia's life is described in terms of deadly suffocation; she says "the house is creakin' like a coffin [...] Sometimes I can't breathe anymore 24". The 1996 production emphasised Portia's restrictive and isolating domestic context so that the focus was not solely on her obsession with the past and Gabriel. Garry Hynes' direction exposed the cultural memory of women's experiences in the Irish home, described by Portia as "this livin' hell ${ }^{25 "}$. Kandis Cook's set and Jim Simmons' lighting design conveyed the claustrophobic confines of the domestic space, anchored by the repeated tableau of Portia sitting in an isolating spotlight at a kitchen table, surrounded by shadows. Presenting Portia as a ghostly body or surrogate that evokes cultural memory, rather than focussing solely on Gabriel's ghost as a surrogate that fills a gap in Portia's unfulfilled life, begs the question, is her life unfulfilled due to his absence or unfulfilled due to the stifling restrictions of the familial and domestic roles she is expected to perform? Richard Kearney suggests that exploration of the past is necessary for the development of our narrative identity:

The challenge, in other words, is to envisage the existence of a narrative self prepared to work through the pain of the past in dialogue with its Others. This would operate as a memoried self who recognizes the limits of remembering whilst resisting the fetishism of the immemorial ${ }^{26}$.

Kearney's memoried self acknowledges the limits of the homely past, thereby avoiding sealing it off from unhomely memories and from the present. Is it possible in performance of the play to enable Portia to operate as a memoried self who enables critical engagement with both individual and cultural memory?

\section{Genealogies of performance and the perpetuation of cultural memory}

Roach's concept of genealogies of performance highlights repeated or reperformed behaviour which is remembered through the body as living memory: "Performance genealogies draw on the idea of expressive movements of mnemonic reserves ${ }^{27}$." Genealogies of performance thus focus on how history and memory are enacted on and remembered through the body. These genealogies are descri-

24. Marina Carr, Portia Coughlan, in Plays One, op. cit., p. 207.

25. Ibid., p. 222.

26. Richard Kearney, Strangers, Gods and Monsters: Interpreting Otherness, London, Routledge, 2003, p. 188.

27. Joseph Roach, op. cit., p. 26. 
bed as "counter-memories" which expose "the disparities between history as it is discursively transmitted and memory as it is publicly enacted by the bodies that bear its consequences ${ }^{28}$ ". Engagement with these counter-memories can attend to the ways in which memory and the past are embodied and performed, and thus question narratives disseminated discursively. Genealogies of performance reiterate the past but they can also cast doubt on their own perpetuations. Portia Coughlan offers two revealing examples of genealogies of performance: firstly, in the community's reaction to Portia's death in Act two, and secondly in Portia's performance in the final scene of Act three as a ghost of a ghost. These scenes highlight the embodiment of cultural codes and the necessity of reperformance to ensure the continuation and adoption of genealogies of performance. However, performance of these scenes can also harness the potential that repetition offers to disrupt and interrogate this process.

The 1996 published script includes stage directions for the opening of Act II which describe the cast's movements in reaction to the discovery of Portia's body. The directions suggest that the cast move as one body: "Ensemble choreography, all movements in unison ${ }^{29}$ ". Portia's swaying body, dripping with water, is juxtaposed with the unified and controlled movements of the cast, directed to "take a step back ... stop ... take another step back ... look up at the dead Portia $a^{30 " . ~ P o r t i a ' s ~}$ uncontrollable body is a "messy visual image" which disrupts the sense of purification and catharsis traditionally created by tragic theatre ${ }^{31}$. The 1996 production utilised the "ensemble choreography" to create a sense of ritual. The cast were motionless and dimly lit in a semi-circle facing the audience while Portia's body became the pivotal point between the audience and cast, once more isolated by a spotlight. The cast stood and watched as Portia's body was lowered and their silence and lack of movement jarred with the noise of the creaking pulley and Portia's suspended body. The sense of ritual was evoked when the cast walked off after Raphael, carrying Portia's body, in a funereal procession of slow and rhythmic pace. The "ensemble choreography" re-enacts the past through ritual, or genealogies of performance, but repetition also creates a sense of the uncanny. The funereal procession was unsettling as the cast seemed more like ghosts or shadows, and therefore more dead, than Portia's swaying and uncontrollable body. The funereal atmosphere was compounded in the scene change that followed when the table which Portia sits at throughout the play was carried on as if it were a coffin born by pallbearers. This served to further underline the claustrophobia of

28. Ibid.

29. Marina Carr, Portia Coughlan, in The Dazzling Dark, Frank McGuinness (ed.), op. cit., p. 272.

30. Ibid.

31. Maria Doyle, "Dead Center: Tragedy and the Reanimated Body in Marina Carr's The Mai and Portia Coughlan”, Modern Drama, 49:1, Spring 2006, 41-59, p. 48. 
Portia's home, thereby offering reasons for her need to escape, even through death. The 2004 production did not create a sense of ritual in this key scene and both the vast sense of space created by Bláithín Sheerin's set design and Paul Keogan's lighting, together with the isolated positioning of the cast, failed to create a sense of imprisonment.

In act three we witness Portia's ghostly return on stage, after we have seen her dead body. Portia therefore functions as a surrogate of the Portia we have seen in act one: a ghost of a ghost. Acts I and II reveal Portia's rejection of traditional models of femininity, contained within the familial and domestic sphere. Portia tells Raphael that she never wanted children and that his belief that he could "woo her into motherhood" has failed: "I can't love them, Raphael. I'm just not able 32 ." Indeed, Portia's relationship with her own mother is fraught and results in violence. Portia's performance in Act III: of the duties of mother and wife, mimics restrictive gender roles. Portia is coerced into performing the roles society makes available to her and this is denoted in the final scene by her putting on the birthday gifts from her husband and parents, a bracelet and dress, before cooking dinner for her husband and putting the children to bed. Portia's ghostly body exposes the disparity between the discursive transmission of history which perpetuates traditional gendered norms, and countermemories which evoke the failure and refusal to fulfil restrictive models of Irish femininity. Portia's ghostly performance highlights counter-memories which are "publicly enacted by the bodies that bear its consequences ${ }^{33}$ " to expose the implications of both repressing and disrupting myths of femininity defined within the domestic space and family unit.

Portia's refusal to fit traditional models of femininity is met by exclusion and denial of her subjectivity. Drawing on Judith Butler's work, Wald maps the "real" and ghostly bodies of the play onto gendered norms to suggest that,

Portia Coughlan offers counter-fantasies to culturally accepted notions about which bodies matter and which do not in terms of life and death but also in terms of appropriately sexed and "unruly" bodies ${ }^{34}$.

Wald argues that Portia's melancholic state unhinges the borders between life and death, male and female; a sentiment echoed by Portia's mother: "If ya passed your day like any normal woman there'd be none of this ${ }^{35}$ !" Portia's mimicry of traditional feminine roles in the final scene of the play evokes a genealogy of performance which "document(s) - and suspect(s) - the historical transmission

32. Marina Carr, Portia Coughlan, in Plays One, London, Faber and Faber, 1999, p. 221.

33. Joseph Roach, op. cit., p. 26.

34. Christine Wald, op. cit., p. 198.

35. Marina Carr, Portia Coughlan, in Plays One, op. cit., p. 211. 
and dissemination of cultural practices through collective representations ${ }^{36 "}$. Wald's reading of Portia as a melancholic suggests that she displays an "inability to conceive of a future that is radically different from the past and present ${ }^{37}$ ". However, unlike Wald, I do not interpret the chronology of the play as reinforcing "the melancholic sense of the future's definiteness and inescapability 38 ". Instead, the third act enables Portia's ghostly performance to critically engage with surrogacy as a process of self-invention which relies on reperformance and thus has the potential to keep the narrative of the past in process. As a ghost of a ghost, Portia highlights the performance of gendered roles, as well as revealing the uncanny potential of the surrogate to evoke counter-memories and the unhomely past. Portia offers a critical genealogy of performance through her engagement with the repression of female subjectivities by restrictive models of femininity, as well as the suggestion of alternatives which refuse to be contained. Gabriel's surrogacy fails to live up to Portia's expectations but her own surrogacy creates a surplus as she exceeds roles through mimicry, underlined by her associations with the Belmont River and her movement beyond the confines of her home.

\section{Environments of memory and the resurfacing of the unhomely past}

In an interview, Carr declared her fascination with "nature invested with human memory or human association ${ }^{39}$ ". The uncanny return and reperformance of the past is closely linked to place in Portia Coughlan. Past actions shape our present world and though genealogies of performance attempt to forget or bury aspects of cultural memory, bodies and the landscape enable these counter-memories to retain a presence and resurface. Roach's discussion of Pierre Nora's concepts of places of memory, "the artificial sites of the modern production of national and ethnic memory", and environments of memory, "the largely oral and corporeal retentions of traditional cultures ${ }^{40}$ ", is particularly useful in its address of the ways in which space functions as a repository of memory. Places of memory are "a place in which everyday practices and attitudes may be legitimated, "brought out into the open", reinforced, celebrated, intensified ${ }^{41}$ ". Roach names these spaces behavioural vortexes as they perpetuate identities and modes of behaviour; they are "a

\footnotetext{
36. Joseph Roach, op. cit., p. 25.

37. Christine Wald, op. cit., p. 196.

38. Ibid.

39. Heidi Stephenson and Natasha Langridge (eds.), "Interview with Marina Carr", Rage and Reason: Women Playwrights on Playwriting, London, Methuen, 1997, p. 146-155, p. 154.

40. Joseph Roach, op. cit., p. 26.

41. Ibid., p. 28.
} 
center of cultural self-invention through the restoration of behaviour ${ }^{42}$ ". Portia's home is a behavioural vortex which legitimates history and provides a space for the re-enactment of the genealogies of performance which Portia is stifled by. The 1996 production's repetition of the tableau at the kitchen table uncannily echoed the restrictive feminized domestic space within the canon of Irish theatre.

Melissa Sihra highlights Portia's sense of dissonance with her home: "In her troubled relationship with home, which she likens to being buried alive, Portia displays a painful manifestation of woman's exile from the Symbolic, which Luce Irigaray identifies as déréliction ${ }^{43}$ ". The absence of adequate cultural representations of woman leads to Portia's incongruence with her home; highlighted in the 1996 production as she sat trapped at the kitchen table and isolated in a spotlight. Portia feels confined by unaccommodating models of femininity and unable to express herself as a desiring subject in the space of the home. The constraining nature of this behavioural vortex was juxtaposed with her corporeal freedom in a scene where she dances at the High Chapparal bar with her friends Stacia and Maggie (act three, scene four). The audience experience the release of Portia's contained energies, an exciting moment which also warns of the danger of further suppressing her frustration and rage. Portia's energy is irrepressible and violently explodes in act three when she leaps onto her mother and pinions her to the ground: "You've me suffocated so I can't breathe any more 44 !" Violence is a means of resistance and expression for Portia; a violence which results in her suicide as a strategy for refusing genealogies of performance and the restrictive space of home.

In Carr's plays watery landscapes evoke freedom from culturally constructed roles and offer a place of possibility for the central women. As Sihra suggests, Portia's "plea for spaces of possibility beyond the monological discourse of home is expressed in her intimate connection with nature 45 ". Through the process of death, the Belmont River offers a space of transformation which can accommodate unexpressed, as well as unstable and ghostly forms of subjectivity. The river is a free flowing space of movement which evokes Portia’s desire for self-invention and renewal. Sihra contends that in Carr's work, "[d]eath on stage does not indicate finality but movement; it is a poetic drive to excavate what it means to live. The plays cannot offer transformative possibility if they are reduced to the literal, where death is regarded in terms of plot rather than poetics ${ }^{46 "}$. As a ghostly surrogate, Portia's life stages the process of death and thus questions "what it means

\section{Ibid.}

43. Melissa Sihra, "The House of Woman and the Plays of Marina Carr", Women in Irish Drama: A Century of Authorship and Representation, Melissa Sihra (ed.), Basingstoke, Palgrave Macmillan, 2007, p. 201-218, p. 210.

44. Marina Carr, Portia Coughlan, in Plays One, op. cit., p. 248.

45. Melissa Sihra, op. cit., p. 201-218, p. 211.

46. Melissa Sihra, "Renegotiating Landscapes of the Female: Voices, Topographies and Corporealities of Alterity in Marina Carr's Portia Coughlan", Australasian Drama Studies, 43, October 2003, 16-31, p. 28. 
to live". In an interview prior to the premiere of Portia Coughlan, Carr remarked that, "[i]n all of us there is a twin. That shadow part of you is often the best part of you. That identity has been fudged or subsumed in Portia, and in a sense, she's like a walking ghost herself ${ }^{47}$ ". Portia's home is a place of memory where she can only mimic the roles she rejects so in order to transform the future, Portia engages with a space outside the domestic confines.

Both the inability to suppress the past and expression of "the shadow part" of the self are strongly associated with the Belmont River. Environments of memory enable the eruption of the forgotten and unhomely past of Irish women's confinement, and resistance, to domestic and familial roles; they can accommodate unhomely bodies who dislocate these roles through performance of alternatives. Like Portia's haunted body, the river enables the resurfacing of repressed cultural memory and the articulation of disruptive female energies which refuse limiting tropes of femininity. Portia's unhomely surrogacy fuses the personal and political through representation of the cultural memory and genealogies of performance which have prescribed woman's role in twentieth century Ireland. If we view Portia as a melancholic, trapped in the past, then the river can be interpreted as a place of memory: a shrine to Gabriel. Conversely, the river can be construed as an environment of memory if we link it to an interrogative female mythmaking, the oral tradition of storytelling and female bodily freedom. Fintan O'Toole's review of the play underscores the breakdown of simple binaries in the flow of the river; a breakdown which facilitates the unsettling resurfacing of the unhomely:

And both landscape and speech belong to the wider set of metaphors that hold the play together, images in which clear distinctions keep breaking down. [...] And in that awful psychic entanglement, the borders between the living and the dead, between male and female, between the born and unborn, between the past and present, dissolve in the river's interminable flow $^{48}$.

The Belmont River disrupts the imposition of fixed roles, and is therefore an environment of living memory which facilitates shifting and unstable identities excluded by traditional gendered spaces. Roach highlights Jonathan Arac's description of a critical genealogy which "aims to excavate the past that is necessary to account for how we got here and the past that is useful for conceiving alternatives to our present condition ${ }^{49}$ ". Portia's haunting genealogy of performance keeps the past in process in order to intervene in the perpetuation of cultural

47. Victoria White, "Twin Speak”, The Irish Times, 19 March 1996.

48. Fintan O’Toole, "Figures on a Dark Landscape”, The Irish Times, 2 April 1996.

49. Joseph Roach, op. cit., p. 25. 
memory but to what extent can she conceive of alternative futures which accommodate expression of her "unruly" subjectivity?

Sue-Ellen Case suggests that in Sarah Kane's 4.48 Psychosis the conflict between the desire for social change and its' failure is its negative utopia. The limits placed on Portia's desire to effect change illustrate this negative dialectic: "the contradiction between the evident possibility of fulfilment and the just as evident impossibility ${ }^{50}$. This contradiction is embodied in the tension between Portia's desires and the regulatory norms which restrict them; the conflict between her agency as suggested in performance and the traditional models of femininity available to her. Anna McMullan describes the struggle of Carr's women to accommodate themselves within the authorised structures of their world: "The trauma of this dislocation is figured through corporeal unhomeliness, taken to its extreme in Carr's female suicides ${ }^{51}$." Portia's ghostliness highlights the discrepancy between the stifling confines of the world she inhabits and her desire for more accommodating spaces. Portia Coughlan functions as a negative utopia as Portia's death simultaneously evokes freedom and constraint: the impossibility of making her unhomely body signify within existing structures. She is therefore doomed to ghostliness within this world but the potential of this uncertain state can be harnessed to put pressure on dominant models of femininity and facilitate the unsettling eruption of the unhomely past of cultural memory.

\section{Demanding alternative futures: the vitality of the ghostly surrogate}

Suicide, for the tragic heroine, is imbued with a sense of fatalism and represents the endpoint of her journey. However, Carr's disruption of linear narrative, together with the intensity of Portia's performance, leaves the audience with a sense of Portia's battle, rather than defeat and closure. Portia's performance can both engage with the past and demand an alternative future by simultaneously highlighting her troubling presence as a ghostly surrogate and her vitality. Cathy Leeney draws attention to the experience of watching a performance of Portia Coughlan, an affective experience which is invigorated by Portia's energy rather than melancholia:

50. Sue-Ellen Case, "The Screens of Time: Feminist memories and hopes", Feminist Futures? Theatre, Performance, Theory, Elaine Aston and Geraldine Harris (eds.), Basingstoke, Palgrave Macmillan, 2006, p. 105-17, p. 111.

51. Anna McMullan, "Unhomely Bodies and Dislocated Identities in the Drama of Frank McGuinness and Marina Carr”, Indeterminate Bodies, Roger Cook, Naomi Segal and Lib Taylor (eds.), Basingstoke, Palgrave Macmillan, 2003, p. 181-191, p. 189. See also, Anna McMullan, "Unhomely Stages: Women Taking (a) Place in Irish Theatre", Druids, Dudes and Beauty Queens, Dermot Bolger (ed.), Dublin, New Island, 2001, p. 72-90. 
In performance, despite her monstrous aspects, Portia's energy fuels the piece, overtaking the negative images of destruction, failure and suicide and enacting, in their stead, a passionate subjectivity of astonishing vigour $^{52}$.

This is echoed by Fintan O'Toole's review of the premiere production, where he remarks upon the necessity of Portia's energy, "for if Portia once settles into any single emotional mode, the play would sink under its own weight ${ }^{53}$ ". Portia may be a ghost of a ghost but the audience are left in no doubt as to her strength of character and refusal to be silenced. The lead actors in both the 1996 and 2004 productions, Dearbhla Crotty and Eileen Walsh, presented intensely moving and passionate portrayals of a woman whose complexity and energy undoubtedly haunted the audience; a haunting which persists in its disturbance of stifling and restrictive models of passive femininity. The sense of Portia's longing for Gabriel is overpowered by the audience's experience of Portia's energy. Leeney suggests that "the energy of human presence in performance celebrates the potential for transformation ${ }^{54}$, and though an alternative world is not given full visual expression, Portia's transgressive energy suggests the freedom generated by the River Belmont.

Ghosting and surrogation can idealize the past, fetishizing it into a fixed and closed narrative sealed off from the future. This occurs when the uncertainty of the uncanny and unhomely is neutralized and fails to trouble the present. Haunting enables the past to be kept alive in the present but it is critical that its presence is questioned through interrogation of our reception of memory and history. Uncanny ghosts and haunted bodies force us to rethink simple binaries of past and present, live and dead, history and memory. Solely focusing on Gabriel's ghost as a surrogate emphasises Portia's unhealthy relationship with a lost and elusive past. However, attending to Portia's role as a ghostly surrogate can shift the focus from an interrogation of individual memory to critical engagement with the unhomely past as perpetuated by cultural memory; this focus on cultural memory was highlighted in the 1996 premiere production. Portia's unity with Gabriel, as well as limiting models of femininity confined within the home and nation, are exposed as myths maintained by surrogation. As surrogates, both Gabriel's ghost and Portia's ghostly body open up fixed narratives of the past to articulate unhomely memories, both individual and cultural. These narratives of the past are thus set in process, enabling engagement with alternatives to perpetuated and limiting norms of femininity. Roach suggests that genealogies of performance can poten-

52. Cathy Leeney, "Ireland's 'exiled' women playwrights: Teresa Deevy and Marina Carr", The Cambridge Companion to Twentieth-Century Irish Drama, Shaun Richards (ed.), Cambridge, Cambridge University Press, 2004, p. 159.

53. Fintan O’Toole, "Figures on a Dark Landscape", The Irish Times, 2 April 1996.

54. Cathy Leeney, "Ireland's 'exiled' women playwrights: Teresa Deevy and Marina Carr”, op. cit., p. 150. 
tially engage with the future, highlighting the "possibilities of restored behaviour not merely as the recapitulation but as the transformation of experience through the displacement of its cultural forms ${ }^{55}$ ". Portia's haunted body recapitulates the past through her mimicry of genealogies of performance in the final scene of the play which, in turn, question and displace inherited models of femininity. Portia's ghostly surrogacy, together with her transgressive and energetic performance, troubles categories of liveable and viable bodies. Portia's suicide can therefore be understood as a rejection of the past and inherited myths of femininity as she demands alternative expression in the river. However, the space of the Belmont River is a negative utopia which articulates the unhomely past of cultural memory in order to convey Portia's rejection of the space of the domestic, while simultaneously signalling the attempt and failure to negotiate representation within legitimated structures.

55. Joseph Roach, op. cit., p. 29. 